\title{
FAKTOR-FAKTOR YANG BERHUBUNGAN DENGAN PENCEGAHAN PENYAKIT INFEKSI MENULAR SEKSUAL (IMS) PADA PEKERJA SOPIR ANGKUTAN UMUM JALUR "H"
}

\author{
Fikram Maswatu ${ }^{1}$ S.L Momot ${ }^{1}$ J.Parlaungan ${ }^{1}$ \\ ${ }^{1}$ Jurusan Keperawatan Politeknik Kesehatan Sorong
}

\begin{abstract}
ABSTRACK
Sexually Transmitted Infections (STIs) are infectious or infectious diseases that are transmitted through sexual contact from the penis, vagina, anal and oral. Preliminary study at the City Health Office of Sorong, the number of data on cases of Sexually Transmitted Infections (STIs) in the last 2 years of 2016-2017 was 122 people consisting of 19 men and 103 women. Objective: To find out the factors related to the prevention of sexually transmitted infections (STIs) in public transport drivers in the " $\mathrm{H}$ " line in Sorong city. Research Method: This type of research is analytic observational using longitudinal cross sectional design. Statistical tests using chi-square consisted of 30 respondents. Independent variables are attitude and use of condoms. Results: Chi-square statistical test results on attitude relations showed $p$ value $0.08>0.05$, which means that there was no relationship between respondents' attitudes towards condom use in taxi driver $\mathrm{H}$. And the results of chi-square statistical tests on attitude relations showed $p$ value $=0.05$ by therefore $p$ value $0.05=0.05$, which means that there is a relationship between the attitude of respondents to condom use in street lane drivers $\mathrm{H}$. Conclusion: There is no correlation between attitude with STI prevention measures on taxi drivers on the $\mathrm{H}$ line and there is a relationship between condom use and STI precautions on $\mathrm{H}$. line taxi drivers.
\end{abstract}

Keywords: Sexually Transmitted Infections, Driver Workers

Bibliography: 1980 - 2016

\begin{abstract}
ABSTRAK
Infeksi Menular Seksual (IMS) adalah penyakit menular atau infeksi yang ditularkan melalui kontak seksual dari penis, vagina, anal dan oral. Studi pendahuluan di Dinas Kesehatan Kota Sorong jumlah data kasus Infeksi Menular Seksual (IMS) 2 tahun terakhir 2016-2017 sebanyak 122 orang terdiri dari 19 orang laki-laki dan 103 orang perempuan. Tujuan : Untuk mengetahui faktor-faktor yang berhubungan dengan pencegahan penyakit Infeksi Menular Seksual (IMS) pada pekerja sopir angkutan umum jalur " $H$ " dikota Sorong.Metode Penelitian : Jenis Penelitian observasional analitik dengan menggunakan rancangan cross sectional longitudional. Uji statistik menggunakan chisquare terdiri dari 30 responden. Variabel independen adalah sikap danVariabel dependen pemakaian kondom. Hasil : Hasil uji statistik chisquare pada hubungan sikap menunjukan $\mathrm{p}$ value $0,08>0,05$ yang artinya tidak hubungan sikap responden terhadap pemakaian kondom di supir taksi jalur H. Dan hasil uji stastistik chisquare pada hubungan sikap menunjukan $\mathrm{p}$ value $=0,05$ oleh karena itu $\mathrm{p}$ value $0,05=0,05$ yang artinya ada hubungan antara sikap responden terhadap pemakaian kondom pada supir taski jalur H.Kesimpulan : Tidak terdapat hubungan antara sikap dengan tindakan pencegahan IMS pada supir taksi jalur $\mathrm{H}$ dan terdapat hubungan antara pemakaian kondom dengan tindakan pencegahan IMS pada supir taksi jalur $\mathrm{H}$.
\end{abstract}

Kata Kunci :Infeksi Menular Seksual; Supir Angkot;Pemakaian Kondom 


\section{PENDAHULUAN}

WHO dan UNAIDS memperkirakan bahwa lebih dari 35,3 juta orang terinfeksi HIV di seluruh dunia dan $90 \%$ dari mereka berada di negara berkembang (UNAIDS, 2013). Di Asia Tenggara Infeksi Menular Seksual(IMS) disebarkan melalui hubungan seksual heteroseksual yang tidak aman, diantaranya pemakaian jarum suntik tidak steril pada pencandu narkoba suntik (UNICEF Indonesia,2012). Data menunjukkan lebih dari 1 juta orang mendapatkan Penyakit Menular Seksual (PMS) per hari, mayoritas hadir tanpa gejala dan dapat meningkatkan risiko penularan human immunodeficiency virus (HIV) tiga kali lipat atau lebih.(UNAIDS, 2013).

Kementerian

Kesehatan

Republik Indonesia Tahun 2014, di seluruh dunia pada tahun 2013 ada 35 juta orang hidup dengan HIV dan 2,1 juta merupakan kasus baru yang terdiri dari 1,9 juta orang dewasa. Di Indonesia ada 79 daerah prioritas dimana epidemi AIDS yang menjangkau delapan provinsi salah satunya Papua Barat (Riau pos, 2013).

Epidemi diPapua Barat disebabkan karena hubungan heteroseksual dan kebiasaan minum alcohol. Data menunjukkan bahwa telah terjadi penularan pada kelompok populasi umum di beberapa wilayah di Papua dan Papua Barat.(Dinkes, 2012)

IMS merupakan golongan penyakit menular atau infeksi yang ditularkan terutama melalui kontak seksual dari orang ke orang melalui penis, vagina, anal dan oral. Penularan dapat juga terjadi dari ibu kepada janin dalam kandungan atau saat kelahiran, melalui produk darah atau transfer jaringan yang telah tercemar, kadangkadang dapat ditularkan melalui alat kesehatan (Lante \& Arsin, n.d.).

Penyakit hubungan seksual berkembang sangat cepat berkaitan seiring pertambahan dan terjadinya migrasi penduduk, bertambahnya kemakmuran, serta terjadinya perubahan perilaku seksual yang bebas. Peningkatan insiden tersebut secara tidak langsung juga terjadi karena semakin banyak kelompok perilaku perilaku berisiko tingggi seperti anak anak, usia remaja, pekerja seks komersial, sopir angkutan umum, pecandu narkoba dll (Manuaba,1999).

IMS memiliki dampak besar pada kesehatan seksual dan reproduksi di seluruh dunia (WHO, 2014). Penyakit Menular Seksual (PMS) adalah satu di antara faktor-faktor penting yang meningkatkan penularan HIV. Apabila tidak ada kebijakan yang tepat dalam memerangi PMS, maka mengurangi penularan HIV akan menjadi sulit. Strategi utama untuk mengontrol PMS adalah melalui meningkatkan Program Pencegahan (SDKI, 2012).

Sopir termasuk dalam kelompok populasi paling berisiko (Dinkes, 2012). Supir angkot adalah salah satu pekerjaan yang beroperasi pada bidang driver atau mengemudi kendaraan beroda empat seperti mobil dan truck. Supir angkot di Kota Sorong khususnya angkutan jalur $\mathrm{H}$ yang beroperasi dengan rute terminal remu sampai dengan km. 13 moyo. Begitupun sebaliknya. Jumlah supir 
jalur $\mathrm{H}$ menurut data Kantor Dinas Perhubungan Darat Kota Sorong per tanggal 17 Mei 2018 sebanyak 30 orang yang terdaftar secara resmi.

Hasil studi pendahuluan pada Dinas Kesehatan Kota Sorong jumlah data kasus IMS dalam 2 tahun terakhir 2016-2017 sekitar 122 orang, 19 orang diantaranya laki-laki. Pada Tahun 2016 penderita IMS yang mengalami Sifilis sebanyak 7 orang 3 orang diantaranya laki-laki, untuk kasus Gonorea sebanyak 3 orang lakilaki, kasus Suspect Gonorea sebanyak 4 orang diantaranya 1 orang laki-laki, kasus Uretrithis Non-Gonorea sebanyak 3 orang laki-laki, Pada kasus HIV/AIDS 2 tahun terakhir 2016-2017, data menunjukkan sebanyak 235 orang dimana diantaranya 109 orang laki-laki.

Tingginya kasus IMS dan besarnya dampak yang ditimbulkan terutama pada kelompok beresiko salah satunya sopir, menjadikan landasan dalam penelitian ini sehingga peneliti tertarik ingin melakukan penelitian mengenai faktor-faktor yang berhubungan dengan pencegahan penyakit infeksi menular seksual (IMS) pada pekerja supir angkutan umum.

\section{METODE}

Jenis penelitian ini menggunakan jenis penelitian observasional analitik dengan menggunakan rancangan cross sectional longitudional. Lokasi penelitian diterminal Remu Jalan Basuki Rahmat Kota Sorong Papua Barat.
Sampel yang digunakan dalam penelitian ini yaitu seluruh total populasi yang diperoleh yang berjumlah 30 orang.

\section{HASIL}

\section{A. Analisis Univariat}

1. Karakteristik Responden Menurut Umur

Tabel 4.2

Karakteristik Responden Menurut Umur

\begin{tabular}{|l|l|c|c|}
\hline No & Umur (Tahun) & Jumlah & $\%$ \\
\hline 1 & $\begin{array}{l}\text { Dewasa Awal } \\
\text { (26-35 tahun) }\end{array}$ & 20 & 66.7 \\
\hline 2 & $\begin{array}{l}\text { Dewasa Akhir } \\
\text { (36-45 tahun) }\end{array}$ & 10 & 33.3 \\
\hline & \multicolumn{2}{|c|}{ Total } & 100.0 \\
\hline \multicolumn{2}{|c|}{ Berdasarkan Tabel 4.1 } & Umur \\
\hline
\end{tabular}
paling banyak pada Umur Dewasa Awal (26-35 Tahun) yaitu 20 orang (66,7\%), dan Umur Dewasa Akhir (36-45 Tahun) yaitu 10 orang $(33,3 \%)$.

2. Karakteristik Responden Menurut Pendidikan

Tabel 4.2

Karakteristik Responden Menurut Pendidikan

\begin{tabular}{|c|c|c|c|}
\hline No & Pendidikan & Jumlah & $\%$ \\
\hline 1 & Pendidikan SD & 5 & 16,7 \\
\hline \multirow[t]{4}{*}{2} & $\begin{array}{l}\text { Pendidikan } \\
\text { SMP }\end{array}$ & 16 & 53,3 \\
\hline & $\begin{array}{l}\text { Pendidikan } \\
\text { SMA }\end{array}$ & 9 & 30,0 \\
\hline & Total & 30 & 100.0 \\
\hline & Berdasarkan & Tabel & 4.2 \\
\hline \multicolumn{4}{|c|}{$\begin{array}{l}\text { menunjukkan Pendidikan terbanyak } \\
\text { pada jenjang SMP yaitu } 16 \text { orang } \\
(53,3 \%) \text {, dan Pendidikan SMA yaitu } 9 \\
\text { orang }(30,0 \%) \text { dan Pendidikan SD } \\
\text { yaitu } 5 \text { orang }(16,7 \%) \text {. }\end{array}$} \\
\hline
\end{tabular}


3. Karakteristik Responden Menurut Penghasilan

Tabel 4.3

Karakteristik Responden Menurut Penghasilan

\begin{tabular}{|l|l|c|c|}
\hline No & \multicolumn{1}{|c|}{ Penghasilan } & $\begin{array}{c}\text { Juml } \\
\text { ah }\end{array}$ & $\%$ \\
\hline 1 & $\begin{array}{l}\text { Di Bawah UMP } \\
(<\text { Rp. }\end{array}$ & & \\
\hline $\begin{array}{l}1.800 .000) \\
2\end{array}$ & $\begin{array}{l}\text { Di Atas UMP } \\
(>\text { Rp. } \\
1.800 .000)\end{array}$ & 21 & 70,0 \\
\hline & Total & 30 & 100.0 \\
\hline
\end{tabular}

Berdasarkan Tabel 4.3, menunjukkan responden paling banyak Di Bawah UMP (< Rp. 1.800.000) yaitu 21 orang (70,0\%), dan Di Atas UMP (> Rp. 1.800.000) yaitu

\section{Sikap}

Tabel 4.4

Sikap Responden Terhadap

Pencegahan Penyakit IMS

Berdasarkan Tabel 4.4 Sikap

\begin{tabular}{|l|c|c|c|}
\hline No & Pencegahan & $\begin{array}{c}\text { Jumla } \\
\text { h }\end{array}$ & $\%$ \\
\hline 1 & $\begin{array}{c}\text { Tidak Ada } \\
\text { Pencegahan }\end{array}$ & 18 & 60,0 \\
\hline 2 & $\begin{array}{c}\text { Ada } \\
\text { Pencegahan }\end{array}$ & 12 & 40,0 \\
\hline & Total & 30 & 100.0 \\
\hline
\end{tabular}

Tabel 4.4 menunjukkan dari 30 responden ada sebanyak 18 tidak melakukan pencegahan (60\%) dan 12 responden melakukan pencegahan $(40 \%)$
5. Pemakaian Kondom

Tabel 4.5

Pemakaian Kondom

Responden Terhadap

Pencegahan Penyakit IMS

\begin{tabular}{|l|c|c|c|}
\hline No & $\begin{array}{c}\text { Pemakaian } \\
\text { Kondom }\end{array}$ & Jumlah & $\%$ \\
\hline 1 & $\begin{array}{c}\text { Tidak } \\
\text { Menggunakan } \\
\text { Kondom }\end{array}$ & 12 & 40,0 \\
\hline 2 & $\begin{array}{c}\text { Menggunakan } \\
\text { Kondom }\end{array}$ & 18 & 60,0 \\
\hline & Total & 30 & 100.0 \\
\hline
\end{tabular}

Berdasarkan Tabel 4.5 Pemakaian Kondom menunjukkan responden paling banyak Tidak Ada Pencegahan yaitu 18 orang $(60,0 \%)$, dan Ada Pencegahan yaitu 12 orang $(40,0 \%)$. 


\section{B. Analisis Bivariat}

1. Hubungan Antara Sikap Responden Dengan Pencegahan Penyakit IMS

Tabel 4.7

Hubungan Antara Sikap Responden Dengan Pencegahan Penyakit IMS

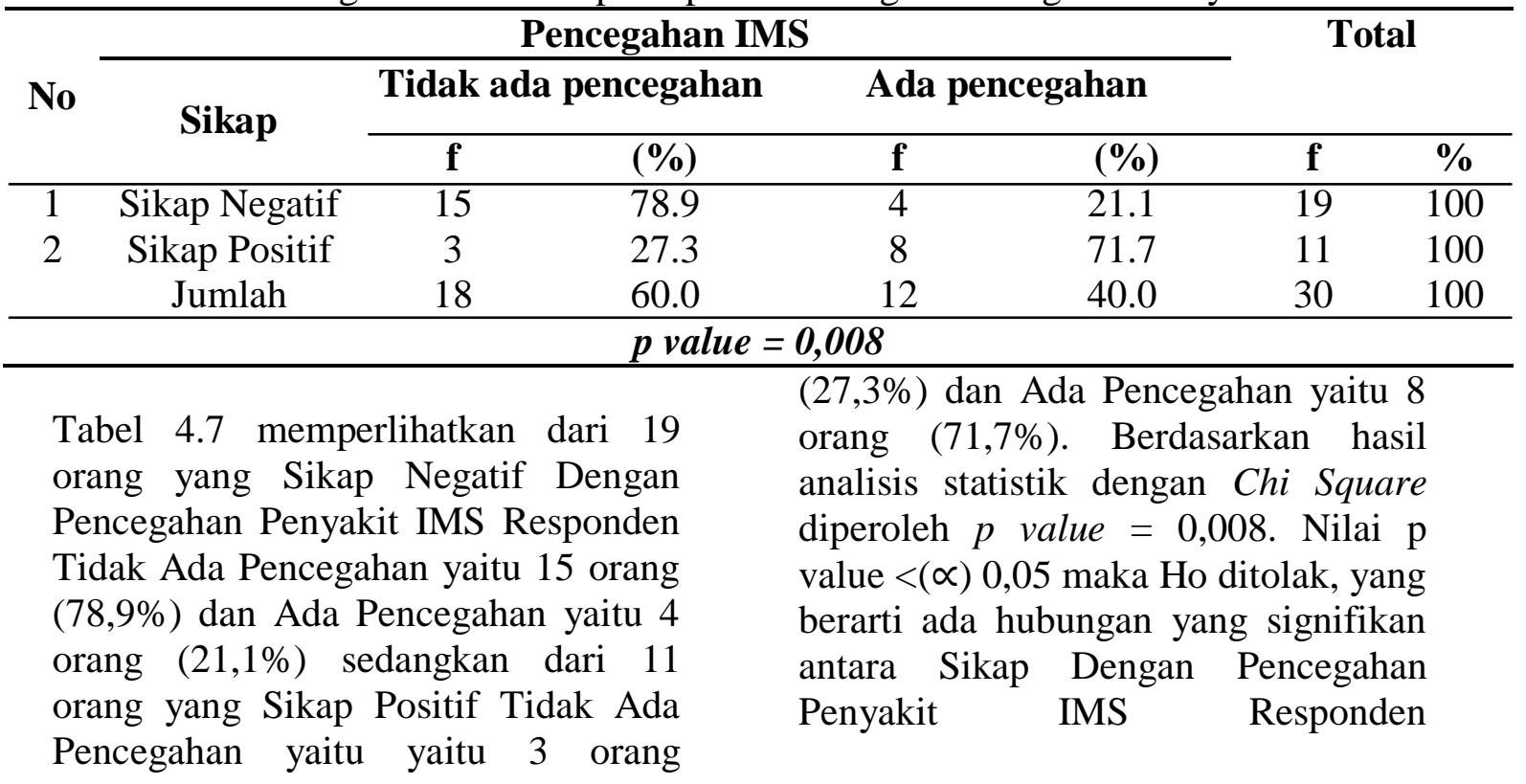

2. Hubungan Antara Pemakaian Kondom Responden Dengan Pencegahan Penyakit IMS

Tabel 4.8

Hubungan Antara Pemakaian Kondom Responden Dengan Pencegahan Penyakit IMS

\begin{tabular}{|c|c|c|c|c|c|c|c|}
\hline \multirow{3}{*}{$\begin{array}{l}\mathbf{N} \\
\mathbf{o}\end{array}$} & \multicolumn{4}{|c|}{ Pencegahan IMS } & \multirow{2}{*}{\multicolumn{3}{|c|}{ Total }} \\
\hline & \multirow{2}{*}{$\begin{array}{l}\text { Pemakaian } \\
\text { Kondom }\end{array}$} & \multicolumn{2}{|c|}{$\begin{array}{c}\text { Tidak ada } \\
\text { pencegahan }\end{array}$} & Ada pencegahan & & & \\
\hline & & $\mathbf{f}$ & (\%) & f & $(\%)$ & f & $\%$ \\
\hline 1 & $\begin{array}{c}\text { Tidak } \\
\text { menggunakan } \\
\text { kondom }\end{array}$ & 8 & 66.7 & 4 & 33.3 & 12 & 100 \\
\hline \multirow[t]{2}{*}{2} & $\begin{array}{c}\text { Menggunakan } \\
\text { kondom }\end{array}$ & 10 & 55.6 & 8 & 44.4 & 18 & 100 \\
\hline & Jumlah & 18 & 60.0 & 12 & 40.0 & 30 & 100 \\
\hline \multicolumn{8}{|c|}{ p value $=0,709$} \\
\hline
\end{tabular}


Tabel 4.8 menunjukkan Dari 18 responden (60\%) yang tidak melakukan pencegahan ada sebanyak 8 orang $(66,7 \%)$ tidak menggunakan kondom dan 10 orang $(55,6 \%)$ menggunakan kondom. Sedangkan 12 responden $(40 \%)$ yang ada pencegahan sebanyak 4 orang $(33,3 \%)$ tidak menggunakan kondom dan sebanyak 8 orang (44.4\%) menggunakan kondom. Berdasarkan hasil analisis statistik dengan Chi Square diperoleh $p$ value $=$ 0,709 Nilai $p$ value $>(\propto) 0,05$ maka Ha ditolak, yang berarti tidak ada hubungan yang signifikan antara Pemakaian Kondom Responden Dengan Pencegahan Penyakit IMS.

\section{PEMBAHASAN}

Hasil penelitian ini membuktikan bahwa suatu sikap belum otomatis terwujud dalam suatu tindakan (overt behavior). Untuk terwujudnya sikap menjadi suatu perbuatan nyata diperlukan beberapa faktor pendukung atau kondisi yang memungkinkan diantaranya fasilitas pelayanan kesehatan yang mudah dijangkau, faktor dukungan (support) dari pihak lain misalnya tokoh masyarakat, petugas kesehatan sangat penting untuk mendukung praktek pencegahan penyakit menular seksual (Notoatmodjo, 1997). Pencegahan IMS secara primer, sekunder dan tertier.

Pencegahan secara primer dengan tidak melakukan hubungan seksual baik vaginal, anal dan oral dengan orang yang terinfeksi adalah satu-satunya cara yang $100 \%$ efektif untuk pencegahan, menggunakan kondom, menjaga kebersihan alat kelamin serta memeriksakan diri ke dokter atau petugas kesehatan apabila mengalami tanda dan gejala penyakit menular seksual seperti rasa sakit atau nyeri pada saat kencing atau berhubungan seksual, rasa nyeri pada perut bagian bawah, pengeluaran lendir pada vagina/ alat kelamin, keputihan berwarna putih susu bergumpal dan disertai rasa gatal dan kemerahan pada alat kelamin atau sekitarnya, keputihan yang berbusa, kehijauan, berbau busuk, dan gatal,timbul bercak-bercak darah setelah berhubungan seks, bintil-bintil berisi cairan, lecet atau borok pada alat kelamin). Sedangkan pencegahan sekunder diantaranya mendapatkan siraman rohani yang dilakukan di lokalisasi, peningkatan pengetahuan tentang IMS melalui penyuluhan dari dinas kesehatan, serta factor pencegahan Tersier diantarnya adanya peraturan dari pemerintah tentang larangan prostitusi dan adanya usaha rehabilitasi dengan pelatihan ketrampilan pada wanita pekerja seksual yang meninggalkan pekerjaan sebagai pekerja seksual. (Sjaiful ,2007) 


\section{SIMPULAN}

Berdasarkan hasil penelitian dapat disimpulkan sebagai berikut :

1. Ada hubungan antara Sikap Responden Dengan Pencegahan Penyakit IMS dengan nilaip value $=0,008$. Nilai $p$ value $<(\propto) 0,05$. Sikap yang negatif 10 kali lebih beresiko untuk tidak melakukan pencegahan IMS dibandingkan dengan sikap yang positif.

2. Tidak Ada hubungan antara pemakaian kondom responden Dengan Pencegahan Penyakit IMS dengan nilai $p$ value $=0,709$. Nilai $p$ value $>(\propto) 0,05$.

\section{SARAN}

Berdasarkan hasil penelitian ada beberapa saran yang dapat peneliti sampaikan yaitu :

1. Dinas Perhubungan dapat bekerja sama dengan dinas kesehatan Kota Sorong untuk penyebaran informasi pada supir melalui edukasi Pencegahan penyakit IMS.

2. Kepada Responden

Hasil penelitian ini diharapkan dapat menambah wawasan informasi dan pendidikan kesehatan tentang pencegahan IMS.

3. Kepada Peneliti Selanjutnya

Penelitian ini masih dalam lingkup local sehingga belum dapat mengeneralisasikan hasil pada semua daerah, maka diperlukan penelitian lanjutan dengan menambah variabel penelitian.

\section{DAFTAR PUSTAKA}

Bagian Obstersi \& Ginekologi. Definisi servisitis, Surabaya : penerbit cv Aneka Ilmu. 1980.

Cambodia Journal. Hubungan Lama kerja dengan kejadian IMS. 2016.

Departemen Kesehatan. Objek sumber permasalahan praktek prostitusi. Jakarta. 2003

Febiyantin Choiriyah. Faktor-faktor yang mempengaruhi kejadian IMS Di Semarang. 2016

Ginanjar. Faktor yang berhubungan dengan kejadian IMS Di Semarang. 2010

Hamilton \& Morga. Infeksi Menular Seksual (IMS), Jakarta : penerbit Universitas Indonesia (UI press), 2009.

Kemenkes RI direktoral jendral pengendalian penyakit dan penyehatan lingkungan. Pedoman IMS. 2011

Manuba. Definisi servisitis, Jakarta : penerbit cv Infomedika, 2010.

Sinclair.Faktor risiko Infeksi Menular Seksual (IMS), Jakarta : cv Infomedika, 2010.

WHO (World Healt Organization), penderita baru IMS, 1999, Jakarta : buku kedokteran, 1999. 